УДК 347.92

DOI https://doi.org/10.32849/2663-5313/2021.1.03

\title{
Олена Захарова,
}

канд. юрид. наук, дочент,

дочент кафедри иивільного прочесу

Інституту права

Київського начіонального університету імені Тараса Шевченка

\section{Олексій Спанчінцев,}

аспірант кафедри иивільного прочесу

Інституту права

Київського начіонального університету імені Тараса Шевченка

\section{ПОНЯТТЯ ТА СУТНІСТЬ СПРОЩЕНОГО ПОЗОВНОГО ПРОВАДЖЕННЯ}

У статті розглядаються питання визначення поняття та сутності спрощеного позовного провадження. Автори досліджують поняття та сутність спрощеного позовного провадження, які покладені законодавцем в основу нормативного регулювання цього процесуального інституту. Автори досліджують поняття та сутність спрощеного позовного провадження з урахуванням наукових дискусій, які присвячені як загальним питанням теорії иивільного процесу щодо позовного провадження, так і особливостям спрощеного позовного провадження.

Здійснено аналіз чинного ЦПК України і зроблено висновок, що ним передбачено як прискорені процедури, так і спрощені процедури. Прискорені процедури можуть стосуватися деяких категорій иивільних справ, наприклад справ окремого провадження. Спрощені процедури також визначаються за предметною ознакою спору (малозначні справи, трудові справи та інші). Спрощення процедури в цих категоріях иивільних справ означає, що не проводиться підготовче засідання та не проводяться судові дебати.

Зроблено висновок, що запровадження такої форми позовного провадження, як спрощене позовне провадження, має створити умови для захисту порушених, невизнаних прав свобод чи інтересів фізичних осіб, прав та інтересів юридичних осіб, інтересів держави у короткі строки.

Зроблено висновок, що спрощене позовне провадження є різновидом позовного провадження $і$ спрямоване на виконання завдань та досягнення мети иивільного судочинства щодо розгляду та вирішення иивільних справ, визначених иивільним процесуальним законодавством за особливою процедурою. Ефективність захисту прав особи має досягатися навіть у разі розгляду та вирішення справи за відсутності сторін на підставі аналізу наявних в справі матеріалів. Зроблено висновок, що ие буде призводити до розвантаження судів та суддів та покращить ситуацію щодо строків розгляду справ у цілому. 3 урахуванням всіх иих факторів відмінність позовного провадження та спрощеного полягає у таких елементах, як складність справи $і$, як виняток, категорія справи.

Ключові слова: цивільний процес, цивільне процесуальне законодавство, позовне провадження, спрощене позовне провадження, суд, сторони.

Постановка проблеми. Актуальність цієі проблематики зумовлена тим, що є нагальна потреба аналізу та напрацювання науково обгрунтованих пропозицій щодо застосування у практичній площині тих змін, які відбулися у цивільному процесуальному законодавстві у жовтні 2017 року [1], відповідно до яких було запроваджено таку форму розгляду і вирішення цивільних справ, як спрощене позовне провадження. Останнім часом реформа процесуального законодавства в цілому та спрощене позовне провадження, його характерні ознаки, процедура розгляду справ активно дискутуються у науковому середовищі. Слід зазначити, що серед науковців немає єдності у поглядах з багатьох питань, крім того, питання поняття та сутності спрощеного позовного провадження залишаються найбільш відкритими для дослідження.

Наші висновки щодо поняття та сутності спрощеного позовного провадження базуються на тих основах, які покладені законодавцем у нормативне регулювання цього процесуального інституту, тих наявних наукових дискусіях, які присвячені як загальним питанням теорії цивільного процесу щодо позовного провадження, так і спрощеному позовному провадженню зокрема, та враховують загальне теоретико-філософське розу- 
міння змісту категорій «поняття» та «сутність». Слід зазначити, що у науці цивільного процесу науковці-процесуалісти приділяли увагу проблемам, які пов'язані з процедурами спрощеного судового розгляду. Такі науковці, як В. І. Бобрик, С. В. Васильєв, О. Зуб, В. В. Комаров, С.О. Короєд, Д. Д. Луспеник, Ю. В. Навроцька О.С. Ткачук, О. Угриновська, С.Я. Фурса, М.Й. Штефан., О. О. Штефан та багато інших, у своїх роботах розглядали питання спрощених процедур, але дискусія триває й досі.

Метою статті $€$ дослідження питання поняття та сутності спрощеного позовного провадження.

Виклад основного матеріалу. У філософії категорія «поняття» розкривається, по-перше, як спосіб розуміння та абстрактного уявлення результатів пізнання певної предметної галузі через усвідомлення істотних характеристик її об'єктів; по-друге, як форма мислення, що характеризується відображенням закономірних відношень та властивостей об'єктів у вигляді думки про їхні загальні та спеціальні ознаки [2, с. 497]. У новому тлумачному словнику української мови 3 лексичної точки зору слово «поняття» також тлумачиться в кількох аспектах. Зокрема, в одному значенні, як і у загально філософському розумінні, воно означає одну з форм мислення, результат узагальнення суттєвих ознак об'єкта дійсності. В іншому - означає розуміння кимсь чого-небудь, що склалося на основі якихось відомостей, власного досвіду; думка про що-небудь, погляд на щось; уявлення, гадка або сукупність поглядів на що-небудь, рівень розуміння чогось $[3$, с. 566]. Отже, в нашому визначенні спрощеного позовного провадження мають бути відображені найсуттєвіші ознаки цього процесуального інституту.

У визначенні спрощеного позовного провадження насамперед нас цікавить співвідношення загального позовного та спрощеного позовного проваджень. Якщо проаналізувати структуру цивільного процесуального кодексу в редакції 03.10.2017 року, то можна побачити, що Глава 10, якою регулюється процедура, що є предметом нашого дослідження, включена до Розділу III, який має назву «Позовне провадження». Не важко зрозуміти, що за своєю структурою цивільний процес побудований за системою проваджень. Такою ж структура процесу була і до реформування 2017 р. Аналізуючи структуру цивільного процесу за ЦПК України 2004 р., В. В. Комаров звертає увагу, що цивільне судочинство є системою проваджень - позо- вного, наказного та окремого, провадження у справі до судового розгляду. Далі він вказує, що з урахуванням інстанційної судової системи і процесуальних функцій судів різних інстанцій структурно цивільне судочинство як система складається з апеляційного, касаційного провадження та провадження справ у Верховному Суді України [4, с. 36]. Автор переконливо доводить (і ми в цьому повністю підтримуємо його точку зору), що позовне провадження є основою цивільного судочинства та правосуддя у цивільних справах. В. В. Комаров визначає провадження цивільного процесу як специфічну конструкцію, морфологічну модель розгляду цивільної справи, що відбиває предметну характеристику цивільного судочинства 3 точки зору матеріально-правової природи справ, що розглядаються, специфіку доказування фактів як юридико-фактологічну основу справи та результатів розгляду справи, які відбиваються у процесуальних актах - документах [4, с. 44].

Як основне провадженням цивільного судочинства, правова природа якого визначається особливостями відповідних матеріальних правовідносин, що характеризуються рівністю суб'єктів, визначають позовне провадження і автори підручника Цивільний процес за редакцією С. О. Харитонова [5, с. 11]. С. В. Васильєва стверджує, що позовне провадження являє собою провадження по вирішенню спорів про «суб'єктивне право цивільне» і спрямоване на захист порушеного або оспорюваного суб'єктивного цивільного права громадян та організацій [6, с. 117]. На думку С. С. Бичкової, позовне провадження $є$ основним і найпоширенішим видом цивільного судочинства [7, с. 9].

Динамічність життя людини, стрімке зростання кількості справ, які розглядалися у порядку цивільного судочинства, спричинили необхідність запровадження прискорених процедур захисту прав особи. С. В. Васильєв визначає прискорене судочинство як форму відправлення правосуддя по окремих категоріях цивільних справ, за якої для ухвалення рішення достатньою є наявність скороченого складу юридичних фактів і обов'язкових процесуальних дій [6, с. 212].

До прийняття ЦПК України 18 березня 2004 року у теорії цивільного процесу існували підходи, згідно з якими структура цивільного судочинства складалася зі стадій. Як зазначав М. Й. Штефан, стадії характеризувалися сукупністю процесуальних правовідносин і дій, об'єднаних найближчою метою [8, с. 30]. В. В. Комаров також звертав увагу на те, що під стадією слід розуміти сукупність процесуальних 
дій суду, учасників процесу, спрямованих на певну процесуальну мету (порушення справи, підготовка справи до судового розгляду та ін.) [4, с. 44].

О. О. Захарова вказувала на те, що стадії як елемент правозастосовного процесу являють собою взаємопов'язані та послідовні етапи процесуальної діяльності, які розкривають зміст кожного 3 етапів провадження. Стадійність цивільного процесу відображає внутрішній взаємозв'язок, проходження одного етапу процесу та здійснення при цьому необхідних і допустимих процесуальних дій.

Далі автор констатує, що кожне провадження, як правило, незалежно від виду судочинства, має такі стадії 1) аналіз фактичних обставин випадку, що розглядається, до якого слід застосувати норму; 2) вибір правової норми; 3) тлумачення норми права стосовно випадку, що розглядається; 4) видання акта застосування вибраної норми; 5) здійснення фактичних дій щодо забезпечення реалізації акта застосування норми; 6) перевірка та контроль за фактичним виконанням акта застосування норми права [9, с. 120] У цьому сенсі можна зробити попередній висновок, що спрощене позовне провадження $€$ похідним від загального позовного провадження і йому притаманні більшість стадій, які є обов'язковими у загальному позовному провадженні.

Якщо звернутись до сутнісної характеристики спрощеного позовного провадження то передусім звертає на себе увагу загальне філософське розуміння категорії «сутність», спрямованої на позначення внутрішньої сукупності істотних властивостей предмета [2, с. 623], тобто головне, визначальне в предметі, що зумовлене глибинними зв'язками й тенденціями розвитку і пізнається на рівні теоретичного мислення. Лексичне значення слова «сутність» тлумачиться як найголовніше, основне, істотне в кому-, чому-небудь; зміст [3, с. 462].

Ще напередодні змін до цивільного процесуального законодавства, розмірковуючи про сутність спрощеного цивільного судочинства, О. С. Ткачук вказував на те, чому виникають складності у визначенні поняття «спрощене провадження». Він звертав увагу на хибність ототожнення «спрощення процедури» із «прискоренням процедури» і виокремлював два чинники, які ускладнюють підходи до визначення: 1) наявність значної кількості різнорідних процедур у цивільному судочинстві, що мають автентичну специфіку в національних процедурах; 2) неоднозначність термінології, що застосовується для дослідження цього феномена.
В основу його висновків покладені підходи, що застосовуються у рамках Ради Свропи, відповідно до яких одним зі способів покращення здійснення правосуддя у розумні строки зі збереженням якості рішень є прискорені провадження, спрямовані на кращу відповідність потребам осіб, які звертаються до суду, і спрощені, або примирні, процедури, розраховані на розгляд простих або безспірних справ. Прискорені провадження стосуються невідкладних питань і пов'язані із: запобіганням безпосередній небезпеці або непоправній шкоді заявнику; забезпеченням доказів; трудовими спорами; справами щодо шлюбних відносин, аліментних зобов'язань; справами, пов'язаними із захистом прав дітей, та ін. Спрощені ж процедури є менш витратними, а процес ухвалення рішень щодо них коротший [10]. Далі науковець зазначає, що за даними CEPEJ, спрощені провадження бувають різних видів (ухвалення рішення одноособово суддею або без проведення судового засідання, або проведення судового засідання у кабінеті судді та ін.).

В іншій своїй роботі науковець вказує на напрями спрощення судових процедур. Він, зокрема, називає удосконалення цивільного судочинства шляхом оптимізації етапів, строків судового провадження у цивільних справах, порядку залучення учасників цивільного процесу до розгляду конкретної справи та зменшення кількості процесуальних дій у межах такого розгляду, а також спрощені судові процедури як форму цивільного судового процесу, яка характеризується визначеним ЦПК України особливим порядком розгляду цивільних справ та прийняттям по них рішення [11, с. 21].

Якщо проаналізувати чинний ЦПК України щодо позовного провадження та процедуру спрощеного позовного провадження, окремого провадження, то ми побачимо, що ним передбачено як прискорені процедури, так і спрощені процедури. Прискорені процедури можуть стосуватися деяких категорій цивільних справ, наприклад справ окремого провадження (про примусову госпіталізацію до протитуберкульозного закладу, про розкриття банком інформації, яка містить банківську таємницю, про надання особі психіатричної допомоги у примусовому порядку). Спрощені процедури також визначаються за предметною ознакою спору (малозначні справи, трудові справи та будь-які інші, за винятком справ, зазначених у ч. 4 ст. 274 ЦПК України). Спрощення процедури в цих категоріях цивільних справ означає, що не проводиться підготовче засідання та не проводяться судові дебати (ч. 3, 8 ст. 279 ЦПК 
України). Ми знов доходимо висновку, що беззаперечним $є$ той факт, що позовне провадження є першоосновою для спрощеного позовного провадження.

Спрощене позовне провадження - це різновид позовного провадження, спрямований на виконання завдань та досягнення мети цивільного судочинства щодо розгляду та вирішення цивільних справ, визначених цивільним процесуальним законодавством за особливою процедурою. Особливість процедури полягає у зменшенні етапів (стадій) справи у суді та оптимізації самого судового розгляду. Так у спрощеному позовному провадженні, як ми вже зазначали, не проводиться підготовче засідання та не проводяться судові дебати (ч. 3, 8 ст. 279 ЦПК України).

За даними судової статистики, майже третина цивільних справ розглядається за правилами спрощеного позовного провадження. Так, тільки згідно з даними, наданими місцевими судами м. Харкова і Харківської області за період з 15.12.2017 року по 01.07.2018 року, у судах першої інстанції м. Харкова і Харківської області розглянуто 6237 справ у порядку спрощеного позовного провадження, що становить 27,09 \% від загальної кількості розглянутих справ (23 023 справи). Також розглянуто 6100 малозначних справ, 137 справ у трудових правовідносинах. У 1172 справах про спрощену процедуру розгляду заявлено клопотання позивачем [12]. Така інформація свідчить про затребуваність цих процедур. Виникає тільки питання: чи $є$ вони ефективними щодо виконання завдань та особливо мети цивільного судочинства стосовно захисту порушених, невизнаних або оспорюваних прав, свобод чи інтересів фізичних осіб, прав та інтересів юридичних осіб, інтересів держави.

Незважаючи на наявність наукової дискусії стосовно сутності, характерних ознак, процедури розгляду та вирішення справ спрощеного позовного провадження, науковці дуже обережно висловлюються стосовно саме визначення поняття цього процесуального інституту. О. Ю. Зуб визначив спрощене провадження як специфічну, додаткову форму розгляду й вирішення цивільних справ, яка грунтується на добровільному підході в його застосуванні, характеризується усіченим складом процесуальних правил у порівнянні із загальним порядком розгляду цивільних справ та закінчується постановленням особливого судового рішення [13, с. 66].

Майже однаковий підхід до визначення спрощеного позовного провадження запропоновано А. Колос. Але вона додатково вказує на те, що ця форма розгляду цивільних справ має певні процесуальні правила, відмінні від загального порядку розгляду цивільних справ. Загальними підставами застосування спрощених проваджень слід вважати безспірність вимог чи малозначність справ, що і породжують їхні особливості, такі як: 1) відсутність потреби у присутності сторін, оскільки документи, що подаються як підтвердження заявлених вимог, є строго у письмовій формі; 2) відсутність потреби у проведенні судового засідання, в тому числі підготовчого; 3) незначна вартість. Усі ці особливості спрощених форм проваджень сприяють оптимізації цивільного судочинства. Вона виділяє такі основні ознаки спрощеного судового провадження у цивільному процесі: 1) особлива процесуальна форма, що зумовлена потребами оптимізації цивільного судочинства; 2) добровільність застосування зацікавленими особами; 3) передбачені процесуальним законодавством два особливі критерії допуску даних спорів до розгляду в спрощеному провадженні: безспірність вимог або малозначність справи; 4) спеціальний режим застосування доказів (документарне провадження, неможливість застосування інституту забезпечення доказів тощо); 5) особливий порядок перегляду судових рішень, що приймаються за результатами розгляду справи за спрощеною процедурою $[14,35]$.

\section{Висновки}

Запровадження такої форми позовного провадження, як спрощене позовне провадження, має створити умови для захисту порушених, невизнаних або оспорюваних прав свобод чи інтересів фізичних осіб, прав та інтересів юридичних осіб, інтересів держави у коротші строки. Ефективність захисту має досягатися навіть у разі розгляду та вирішення справи за відсутності сторін на підставі аналізу наявних у справі матеріалів, що буде призводити до розвантаження судів та суддів і створювати позитивну динаміку щодо строків розгляду справ в цілому. 3 урахуванням всіх цих факторів відмінність позовного провадження та спрощеного полягає у таких елементах, як складність справи i, як виняток, категорія справи. На підставі всього вище наведеного ми можемо зробити висновок, що спрощене позовне провадження це така форма позовного провадження, яка спрямована на виконання завдань та досягнення мети цивільного судочинства щодо розгляду та вирішення окремих категорій цивільних справ, визначених цивільним процесуальним законодавством за скороченою процедурою у розумні строки. 


\section{Список використаних джерел:}

1. Цивільний процесуальний кодекс України від 18 березня 2004 p. URL: http://zakon5.rada. gov.ua/laws/show/v0004740-13 (дата звернення: 02.01.2021).

2. Філософський енциклопедичний словник. Київ: Абрис, 2002. 744 с.

3. Новий тлумачний словник української мови : у 4-х томах. Т. 3. Київ.: Видавництво «Аконіт», 1999. $928 \mathrm{c}$

4. Комаров В.В. Курс цивільного процесу : підручник/ за ред. В.В. Комарова. Харків: Право, 2011. 1352 c.

5. Цивільний процес України : підручник / за ред. С. О. Харитонова, О. I. Харитонової, Н. Ю. Голубєвої. Київ : Істина, 2011. 536 с.

6. Васильев С.В. Гражданский процесс: курс лекций. Харьков: Эспада, 2010. 866 с

7. Бичкова С. С. Цивільний процесуальний правовий статус осіб, які беруть участь у справах позовного провадження : монографія. Київ : Атіка, $2011.420 \mathrm{c}$.

8. Штефан М.Й. Цивільне процесуальне право України: Академічний курс : підручник. Київ: Ін Юpe, 2005. 624 c.
9. Захарова О.С. Відновлення втраченого провадження: порівняльний огляд процесуального законодавства. National law journal: theory and practice. 2016. № 6. C. 116-122.

10. Ткачук O.C. Спрощене провадження: правова природа, ознаки, процедура URL: https:// zib.com.ua/ua/129257-sproschene_provadzhennya pravova priroda oznaki procedura.html (дата звернення: 02.01.2021).

11. Ткачук О. Сучасні проблеми і напрямки спрощення судових процедур у цивільному судочинстві України. Підприємниитво, господарство $i$ право. 2016. № 5. С. 19-24.

12. Узагальнення судової практики по спрощеному позовному провадженню в судах першої інстанції та Апеляційному суді Харківської області URL: https://hra.court.gov.ua/sud2090/ inf_court/generalization/uzag18c11 (дата звернення: 02.01.2021).

13. Зуб О.Ю. Спрощене провадження як модель цивільного судочинства. Проблеми законності: 2015. Вип. 131. С. 62-70.

14. Колос А. Теоретичні проблеми спрощеного провадження у цивільному процесі. Підприємниитво, господарство і право. 2019. № 4. С. 32-35.

Olena Zakharova, Oleksiy Epanchintsev. The concept and essence of simplified litigation

The article considers the definition of the concept and essence of simplified litigation. The authors explores the concept and essence of simplified litigation on the basis laid down by the legislator in the regulatory regulation of this procedural institution. The authors explores the concept and essence of simplified litigation, taking into account scientific discussions, which are devoted to both general issues of the theory of civil procedure for litigation and the features of simplified litigation.

An analysis of the current CPC of Ukraine was made and it was concluded that it provides for both accelerated and simplified procedures. Expedited procedures may apply to certain categories of civil cases, such as separate proceedings. Simplified procedures are also determined by the subject matter of the dispute (minor cases, labor cases, etc.). Simplification of the procedure in these categories of civil cases means that there is no preparatory hearing and no court debate.

It is concluded that the introduction of such a form of litigation as simplified litigation should create conditions for the protection of violated, unrecognized rights, freedoms or interests of individuals, rights and interests of legal entities, the interests of the state in the short term.

It is concluded that the simplified claim proceedings are a kind of claim proceedings and are aimed at fulfilling the tasks and achieving the goal of civil proceedings in considering and resolving civil cases defined by civil procedural law under a special procedure. The effectiveness of the protection of individual rights should be achieved even when considering and resolving the case in the absence of the parties on the basis of analysis of the materials available in the case. It is concluded that this will lead to the unloading of courts and judges and will improve the situation regarding the terms of consideration of cases as a whole. Taking into account all these factors, the difference between litigation and summary proceedings lies in such elements as the complexity of the case and, as an exception, the category of the case.

Key words: civil process, civil procedural legislation, claim proceedings, simplified claim proceedings, court, parties. 